much longer period in selected cases. Long-term anticoagulant therapy should also be considered in patients after the first embolic episode, both in sinus rhythm and in atrial fibrillation. This is our present practice.

We intend to continue and to extend this study in the hope that it will enable us to define the place of anticoagulant treatment in the prevention of systemic embolism in rheumatic heart disease in a more satisfactory manner. It is, of course, fully appreciated that this aim can be achieved only if the study includes a proper control group. At the same time it should be emphasized that a more rational long-term approach to this problem is the prevention of the development of a vulnerable stage of the underlying rheumatic disease. Antistreptococcal prophylaxis should be introduced very early in the course of rheumatic cardiac involvement, and certainly before the valvular lesion has reached a degree severe enough to lead to significant haemodynamic alterations and to progressive cardiac changes irrespective of future rheumatic activity.

\section{Summary}

The risk of systemic embolism is assessed in a group of 754 patients with chronic rheumatic heart disease followed over a period of 5,833 patient-years.

The incidence of embolism was $1.5 \%$ per patient-year for the whole group. It was seven times higher in atrial fibrillation than in sinus rhythm. When the duration of atrial fibrillation was known, it was found that one-third of the emboli occurred within one month and two-thirds within 12 months after the onset of atrial fibrillation. The incidence of embolic recurrences was $8 \%$ per patient-year, irrespective of the nature of the cardiac rhythm, but $66 \%$ of the recurrences took place within 12 months of the initial embolic episode.

Mitral valvotomy did not eliminate the danger of embolism. It is questionable whether it reduced its incidence.

Anticoagulant treatment reduced the incidence of embolic recurrences.

\section{REFERENCES}

Askey, J. M. (1957). Systemic Arterial Embolism, pp. 28, 102. Grune and Stratton, New York.

__ and Bernstein, S. (1960). Progr. cardiovasc. Dis., 3, 220.

Bannister, R. G. (1960). Lancet, 2, 329.

Belcher, J. R., and Somerville, W. (1955). Brit. med. f., 2, 1000.

Cosgriff, S. W. (1950). F. Amer. med. Ass., 143, 870.

Daley, R., Mattingly, T. W., Holt, C. L., Bland, E. F., and White, P. D. (1951). Amer. Heart F., 42, 566.'

Douglas, A. S. (1962). Anticoagulant Therapy, p. 220. Blackwell, Oxford.

Ellis, L. B., and Harken, D. E. (1961). Amer. Heart f., 62, 611.

Estes, D. (1961). Amer. F. Med., 30, 449.

Greenwood, W. F., Aldridge, H. E., and McKelvey, A. D. (1963). Amer. 7. Cardiol., 11, 348.

Harris, A. W., and Levine, S. A. (1941). Ann. intern. Med., 15, 637.

Kellogg, F., Chi Kong Liu, Fishman, I. W., and Larson, R. (1961). Circulation, 24, 263.

Lowther, C. P., and Turner, R. W. D. (1962). Brit. med. f., 1, 1027.

Olesen, K. H. (1955). Mitral Stenosis, p. 139. Munksgaard, Copenhagen.

Owren, P. A. (1963). Arch. intern. Med., 111, 240.

Ricordeau, G., Coblentz, B., and Lenègre, J. (1957). Arch. Mal. Cour, 50, 112.

Riss, E., and Levine, S. A. (1958). Amer. Heart f., 56, 831.

Rowe, J. C., Bland, E. F., Sprague, H. B., and White, P. D. (1960). Ann. intern. Med., 52, 741 .

Taber, R. E., and Lam, C. R. (1960). Circulation, 22, 821.

Wang, Y., Bland, E. F., and Scannell, J. G. (1960). Ibid., 22, 829.

Wood, J. C., and Conn, H. L. (1954). Ibid., 10, 517

Wood, P. (1954). Brit. med. f., 1, 1051. 552. Eyre and Spottiswoode, London.

Wright, I. S. (1949). Ann. intern. Med., 30, 80

and Foley, W. T. (1947). Amer. Ұ. Med., 3, 718.

\title{
Isolation of a Reovirus from a Case of Burkitt's Lymphoma
}

\author{
T. M. BELL,* B.SC., PH.D. ; ALEXANDER MASSIE,* A.I.M.L.T. ; M. G. R. ROSS,* B.SC. \\ MILES C. WILLIAMS, $\dagger$ M.B., B.S., D.T.M.\&H.
}

Brit. med. F., 1964, 1, 1212-1213

The lymphoma syndrome first described by Burkitt in 1958 is found over large areas of tropical Africa. The age of maximum incidence of the disease is 5-6 years, and from the evidence of his safaris Burkitt (1962) has concluded that the data are not inconsistent with a postulated arbovirus aetiology. The suggestion of a virus aetiology first came from J. N. P. Davies (see Burkitt, 1962).

Previous attempts to isolate viruses from the lymphoma in vitro gave Herpes hominis from 6 out of 50 biopsies (Woodall and Haddow, 1962 ; Simons and Ross, 1963), and a virus which might well be of the herpes group has been seen by Epstein et al. (1964) in cultured cells from a Burkitt tumour. Dalldorf and Bergamini (1964) recovered six strains of virus from lymphomas in Kenya. These were compared with ethersensitive viruses and tested against the adenovirus group antigen.

This preliminary study reports the isolation of a reovirus, probably related antigenically to type 3 , from Maitland-type cultures of a Burkitt tumour biopsy. This would also appear to be the first recovery of a reovirus in East Africa.

\footnotetext{
* Imperial Cancer Research Fund, East African Virus Research Institute, P.O. Box 49, Entebbe, Uganda. † East African Virus Research Institute.
}

\section{Materials and Methods}

Media A, C, and E were prepared as described by Bell (1962). Calf serum and Eagle's MEM (Eagle, 1959) were supplied by Microbiological Associates Inc. Medium F was prepared by adding $10 \%$ calf serum to the MEM.

Human embryo kidney (H.E.K.), hamster kidney (Ham.K.), vervet monkey kidney (M.K.), and human amnion (H.A.) cell cultures were prepared by standard techniques (Bell et al., 1960 ; Bell, 1962), and trypsinized human embryo lung fibroblasts (H.E.Lu.) by the method of Hayflick and Moorhead (1961).

Tumour biopsies were collected from four cases of lymphoma at Mulago Hospital, Kampala, and kept in medium $\mathrm{A}$ at room temperature until treated. Maitland-type cultures (Maitland and Maitland, 1928) were prepared in medium C in stationary tubes or plastic Petri dishes (Gateway International) and incubated at $37^{\circ} \mathrm{C}$.

Aliquots of $0.2 \mathrm{ml}$. of the suspensions of cells which grew from these biopsies were inoculated into roller-tube cultures of H.A., Ham.K., M.K., and H.E.Lu., and of $0.5 \mathrm{ml}$. into Petri-dish cultures of M.K. cells. Medium A was used for the maintenance of tube cultures and medium $F$ for plate cultures. 
Neutralization tests were carried out by preparing serial doubling dilutions of serum in 2.6- $\mathrm{ml}$. volumes of medium A and adding $1.3 \mathrm{ml}$. to each of two tubes of $\mathrm{MK}$ or Ham.K. cell cultures. Then $0.2 \mathrm{ml}$. of medium A containing $100 \mathrm{TCD}_{50}$ of virus was added to each tube. The tubes were incubated at $37^{\circ} \mathrm{C}$. in roller drums until the virus controls were positive. The serum titres were calculated as the $50 \%$ end-point by the method of Reed and Muench (1938).

Monkey antisera to reovirus types 1,2 , and 3 were kindly supplied by Dr. M. H. Hambling, Central Public Health Laboratory, Colindale, England.

\section{Results}

Isolation.-A virus was isolated in Petri-dish cultures of $\mathrm{MK}$ cells inoculated with cells and tissue-culture fluid from a Petri-dish culture of biopsy CAN 230. This biopsy was taken from a lymphoma of the left cheek of a 5-year-old African boy and was confirmed histologically as a Burkitt tumour (D. H. Wright, personal communication). The virus was passed to Ham.K. and H.A. cell cultures in which a cytopathic effect similar to that of reovirus was produced. After three further passages in Ham.K cells and one in M.K., the agent titred $10^{-5.5}$ per $\mathrm{ml}$. in H.E.Lu, and $10^{-6.0}$ per $\mathrm{ml}$. in Ham.K., H.E.K., and M.K. This sixth-passage material was used to prepare a large batch of virus in M.K. cells for further study.

Properties.-The virus withstood six cycles of freezing and thawing, and there was no increase in titre when the cells were disrupted. When examined by electron microscopy M.K. cells infected with sixth-passage virus were seen to be packed with reovirus-like particies ( $R$. Dourmashkin, personal communication). The virus retained its pathogenicity after overnight treatment with $20 \%$ diethyl ether.

Serological Identification.-Since the virus was originally grown in M.K. cells the possibility of a simian origin had to be considered. Serum obtained from the monkey which provided the kidney contained no detectable neutralizing antibody at a dilution of $1: 4$. Antiserum to reovirus type 3 neutralized the agent whereas antisera to types 1 and 2 did not.

Pathogenicity for Mice.-No agent was isolated when a $10 \%$ suspension of biopsy material in $0.75 \%$ bovine plasma albumin (Armour fraction $\mathrm{V}$ ) in a phosphate buffer of $\mathrm{pH} 7.2$ was inoculated direct into two litters of newborn mice, intracerebrally, intraperitoneally, and subcutaneously. Tissueculture virus of the fifth passage which titred $10^{-5}$ per $\mathrm{ml}$. in M.K. cells when titrated in newborn mice by the intracerebral route gave a titre of $10^{-5.5}$ per $\mathrm{ml}$. An ether sensitivity test with a different tissue-culture suspension showed the agent to be ether-resistant. After intracerebral inoculation with fifthpassage tissue-culture material newborn mice became sick between the ninth and tenth days and died between the twelfth and seventeenth days, whereas with seventh-passage material sickness and death were observed on the seventh and eighth days. Passage of brain suspension from these mice to newborn mice resulted in sickness and death on the sixth day. Oneday-old mice inoculated intraperitoneally also died.

Antibody Surveys.-Serum specimens from 26 cases of Burkitt's lymphoma (including the case from which the virus was isolated), one case of histiocytic lymphoma, and 13 controls were tested for neutralizing capacity. The control sera were all collected from the village of Aliba, in the West Nile Region of Uganda, from healthy individuals, mostly children. Three cases of Burkitt's lymphoma had been recorded in this village in the preceding two years. The results of these tests are shown in the Table. It will be seen that 21 out of 26 sera from cases of Burkitt's lymphoma had antibody titres of $1: 4$ or more and only 3 out of the 14 controls (including the histiocytic lymphoma). Although the numbers are too few to allow any firm conclusions to be drawn, the probability of this difference being a chance occurrence is less than $0.1 \%\left(\chi^{2}=11.05,1\right.$ d.f. $)$.

\begin{tabular}{|c|c|c|c|c|c|c|c|c|}
\hline \multirow{2}{*}{ Case } & \multirow{2}{*}{$\begin{array}{c}\text { No. } \\
\text { Tested }\end{array}$} & \multicolumn{7}{|c|}{ Neutralization Titres } \\
\hline & & $<4$ & 4 & 6 & 8 & 11 & 16 & 32 \\
\hline $\begin{array}{l}\text { CAN } 230 \\
\text { Burkitt's lymphoma } \\
\text { Histiocytic } \\
\text { Normal children }\end{array}$ & $\begin{array}{r}1 \\
25 \\
1 \\
13\end{array}$ & $\frac{5}{11}$ & $\frac{6}{6}$ & $\overline{2}$ & $\frac{9}{1}$ & $\overline{1}$ & $\frac{1}{2}$ & $\overline{1}$ \\
\hline
\end{tabular}

\section{Discussion}

The virus, CAN 230, has been isolated from a culture of tumour tissue from a proved case of Burkitt's lymphoma. It is (a) ether-resistant, (b) cytopathogenic for a wide range of cells in culture, $(c)$ pathogenic for suckling mice, $(d)$ liberated into the medium of completely degenerated cell cultures, $(e)$ similar in size and morphology to a reovirus, $(f)$ neutralized by reovirus type 3 antiserum, and $(g)$ neutralized by some human sera.

These properties show that CAN 230 is a reovirus almost certainly related antigenically to type 3 (Sabin, 1959). The exact relationship has still to be determined by reciprocal neutralization tests.

A preliminary survey of the cases of Burkitt's lymphoma suggests a higher incidence of neutralizing antibody in the sera from lymphoma patients than in the sera from normal children in a "lymphomatous area."

Reoviruses are among the most widespread of viruses. Strains related to those which can infect man have been isolated from monkeys, dogs, cattle, mice, insects (including mosquitoes), and even plants (Hartley et al., 1961 ; Rosen, 1962 ; Lou and Wenner, 1963 ; Streissle and Maramorosch, 1963).

It is too early yet to assume an aetiological role for reoviruses in the Burkitt tumour, but, equally, this possibility cannot be excluded and is being further investigated.

\section{Summary}

A virus, antigenically related to reovirus type 3 , has been isolated from a case of Burkitt's lymphoma. Preliminary serological testing suggests a significantly higher incidence of antibody in lymphoma patients than in healthy children. The implications of these results are discussed.

We wish to thank Dr. R. Dourmashkin, who helped to identify the virus by electron microscopy. The individuals and organizations, both in Uganda and the United Kingdom, who made this work possible are too numerous to mention in this preliminary communication, and they will be listed in subsequent publications.

\section{REFERENCES}

Bell, T. M. (1962). Scot. med. F., 7, 85.

Turner, G., Macdonald, A., and Hamilton, D. A. (1960). Lancet, 2, 1327 .

Burkitt, D. (1958). Brit. F. Surg., 46, 218.

- (1962). Postgrad. med. F., 38, 71

Dalldorf, G., and Bergamini, F. (1964). Proc. nat. Acad. Sci. (Wash.), $51,263$.

Eagle, H. (1959). Science, 130, 432.

Epstein, M. A., Achong, B. G., and Barr, Y. M. (1964). Lancet, 1, 702. Hartley, J. W., Rowe, W. P., and Huebner, R. J. (1961). Proc. Soc. exp. Biol.' (N.Y..), 108, 390 .

Hayflick, L., and Moorhead, P. S. (1961). Exp. Cell Res., 25, 585.

Lou, T. Y., and Wenner, H. A. (1963). Amer. F. Hyg., 77, 293.

Maitland, H. B., and Maitland, M. C. (1928). Lancet, 2, 596.

Reed, L. J., and Muench, H. (1938). Amer. 7. Hyg., 27, 493.

Rosen, L. (1962). Ann. N.Y. Acad. Sci., 101, 461.

Sabin, A. B. (1959). Science, 130, 1387.

Simons, P. J., and Ross, M. G. R. (1963). A.R. imp. Cancer Res. Fd, p. 48.

Streissle, G., and Maramorosch, K. (1963). Science, 140, 996.

Woodall, J. P., and Haddow, A. J. (1962). E. Afr. Virus Res. Inst. Rep., p. 30 . 